\title{
Kondisi Unggulan Sumberdaya Pelagis Kecil Berdasarkan Data Di Wilayah Pengelolaan Perikanan Negara Republik Indonesia (Wppnri) 712 Dan 573 Tahun 1990 - 2017 Provinsi Jawa Timur Dalam Rangka Pengelolaan Yang Berkelanjutan
}

\section{Leading Condition Of Small Pelagic Resources Based On Data In The State Fisheries Management Area Of The Republic Of Indonesia (Wppnri) 712 And 573 Year 1990 - 2017 East Java Province For Sustainable Management}

\author{
Tri Djoko Lelono, Muhammad Arif Rahman, Gatut Bintoro, Nita Hellis Setyowati, Nindi \\ Nur Wulandari \\ Department of Fisheries and Marine Resource Utilization, Faculty of Fisheries and Marine Science, \\ Universitas Brawijaya, Veteran Street, Malang, East Java, Indonesia \\ *Corresponding author: Email t.djoko@ub.ac.id
}

Submitted: 22 June 2021 Revised: 09 July 2021

Accepted: 22 July 2021 Publish: 31 July 2021

\begin{abstract}
ABSTRAK
Sumberdaya ikan pelagis memiliki peranan yang sangat penting dalam pengembangan ekonomi wilayah. Adanya anggapan bahwa sumberdaya ikan merupakan milik bersama (common property) sehingga semua orang bebas melakukan penangkapan (open acces) menjadi masalah terjadinya overfishing di perairan Jawa Timur. Tujuan dari penelitian ini yaitu mengetahui komoditas unggulan ikan pelagis kecil, status pengusahaan sumberdaya ikan ungulan dan menyusun skenario pengelolaan berkelanjutan sumberdaya unggulan. Metode dalam penelitian ini yaitu metode deskriptif kuantitatif dengan dengan analisis data yang digunakan diantaranya Location Quotient (LQ), Schaefer (1954), Fox (1970), Walter Hilborn, dan pemrograman STELLA (System Thinking, Experimental Learning Laboratory with Animation). Hasil penelitian spesies unggulan di Provinsi di Selatan Jawa Timur) yaitu ikan lemuru, sedangkan unggulan ikan di Kabupaten adalah ikan sunglir. Status perikanan pada tingkat pengusahaan perikanan unggulan di Selatan Jawa Timur, tingkat pengusahaan ikan lemuru sebesar $240 \%$ dengan status Depleted. Terakhir tingkat pengusahaan untuk ikan sunglir sebesar $689 \%$ yang artinya masuk kedalam depleted. Skenario pengelolaan berkelanjutan perikanan pelagis untuk 10 tahun mendatang yaitu tahun 2018 - 2027 untuk ikan lemuru didapatkan cadangan biomassa tertinggi tahun 2027 yaitu menggunakan alokasi effort tetap yang memiliki cadangan biomassa sebesar $179 \%$ dan nilai potensi cadangan lestari sebesar 8.438,48 ton. Hasil penelitian diperoleh komoditas unggulan ikan pelagis kecil di utara jawa timur didapatkan ikan kembung. Komoditas unggulan ikan di Kabupaten/Kota didapatkan ikan tetengkek. Tingkat pengusahaan ikan kembung sebesar $127 \%$ dengan status Over Exploited, dan tingkat pengusahaan ikan tetengkek sebesar $131 \%$ dengan status Over Exploited. Skenario pengelolaan komoditas unggulan ikan kembung didapatkan cadangan biomasa tahun 2027 tertinggi pada alokasi upaya penangkapan diperbolehkan $\left(\mathrm{f}_{\mathrm{JTB}}\right)$ sebesar $129 \%$.

Kata Kunci: Status Pengusahaan, Tingkat Pengusahaan, Komoditas Unggulan, , Potensi Lestari,
\end{abstract} STELLA,

\section{ABSTRACT}

Pelagic fish resources have a very important role in regional economic development. The assumption that fish resources are common property so that everyone is free to catch (open access) is a problem with overfishing in East Java waters. The purpose of this study is to determine the superior commodity of small pelagic fish, the status of exploitation of superior fish resources and to compile a scenario of sustainable management of superior resources. The method in this research is quantitative descriptive method with data analysis used including Location Quotient (LQ), Schaefer (1954), Fox (1970), Walter Hilborn, and programming STELLA (System Thinking, Experimental Learning Laboratory with 
Animation). The research result of the superior species in the province in the south of East Java) is sardin, while the superior fish in the regency is s Rainbow runner. The status of fisheries at the level of superior fisheries exploitation in South East Java, the level of exploitation of ssrdin fish is $240 \%$ with the status of Depleted. Finally, the level of exploitation for s Rainbow runner fish is $689 \%$, which means that they are included in depleted. The scenario of sustainable management of pelagic fisheries for the next 10 years, namely 2018 - 2027 for lemuru fish, the highest biomass reserves will be obtained in 2027, using a fixed effort allocation which has biomass reserves of $179 \%$ and the potential value of sustainable reserves of $8,438.48$ tonnes. The results showed that the superior commodities of small pelagic fish in North East Java were mackerel fish. The superior fish commodity in the Regency / City is obtained by Finny scad fish. The level of exploitation for mackerel is $127 \%$ with the status of Over Exploited, and the level of exploitation for Finny scad is $131 \%$ with the status of Over Exploited. The scenario for the management of the superior mackerel commodity, the highest biomass reserve in 2027 is the allowable fishing effort allocation (fJTB) of $129 \%$.

Key Words: STELLA ,Superior commodity, Fishery status, Sustainable potential

\section{PENDAHULUAN}

Sumberdaya ikan pelagis kecil memberikan kontribusi yang tinggi pada tempat pendarat ikan, sebagai komponen penting dalam ekosistem laut, sedangkan populsi ikan pelagis kecil menunjukkan variasi yang luas dalam ukuran populasi mereka, yang memiliki konsekuensi ekologi dan sosial ekonomi yang penting, ( FAO, 2018, I. Palomera et al 2007, J. Alheit et al 2019]. Disamp[ing itu kan pelagis merupakan ikan yang berkelompok, berenang bebas dengan waktu yang lama serta cukup jauh dengan membentuk Schoaling, hidup pada daerah lapisan permukaan lautan. dapat melakukan migrasi secara vertikal maupun horizontal mendekati permukaan dan mereka berenang dengan tenang untuk waktu yang lama, mencari habitat yang lebih sesuai yang dipengaruhi oleh osceanograph, Ikan pelagis kecil pada umumnya dikategorikan pada ukuran 5-50 cm.(Cushing 2018, Nelwan 2015, Rasyid 2009,Suca et al., 2018,) Pengelolaan sumberdaya ikan pelagis secara berkelanjutan dengan memperhatikan kaidah-kaidah konservasi dan kesejahteraan masyarakat belum dilakukan secara efektif. Maka untuk mencegah penurunan suatu sumberdaya baik dilihat pada ikan maupun lingkungan, perlu menerapkan kehati hatian setiap tahapan manajemen sumberdaya perikanan. Sehingga dengan mengenali dan memahami fenomena perubahan dan kerusakan sumberdaya perikanan dengan baik, maka semakin dapat menyikapi dengan lebih baik sumberdaya tersebut umtuk mencapai keberlanjutan. Menurut Ghosh dan Kar (2013), penggunaan sumberdaya hayati secara berkelanjutan merupakan salah satu peranan penting saat ini untuk 
memenuhi kebutuhan manusia dalam jangka panjang

Pemanfaatan berkelanjutan sumber daya ialah pemanfaatan sumber daya untuk kepentingan pemenuhan kebutuhan manusia sekarang yang sekaligus tidak mengabaikan kebutuhan generasi yang akan datang terhadap sumber daya tersebut. Gammanpila (2019), mengatakan bahwa di dunia perikanan saat ini dalam keadaan krisis karena eksploitasi berlebih dan tidak diterapkannya strategi menejemen. Dalam hal ini perlu adanya upaya dalam menjalannya fungsi strategi menejemen agar perikanan akan sustainable (berkelanjutan). Disampin itu sumberdaya perikanan akan collapse pada tahun 2048 jika setiap tahunnya menurun $27 \%$ dari maksimum hasil panen dan jika setiap tahunnya (t) stok menurun $<10 \%$ maka stok akan runtuh pada tahun ke $t$ bisa disebabakan oleh disebabkan oleh (a) kebijakan/aturan (b) lingkungan (c) pasar (d) kekuasaan/pemerintah dan (e)data base yang salah (Branch, (2008, Worm Boris et al (2006) Jika kondisi ini terjadi peran manusia sebagai pengeskploitasi hanya bisa menunda tidak bisa mencegah.
Eksplorasi dan eksploitasi sumberdaya ikan, diperlukan adanya dugaan potensi sumberdaya perikanan yang dapat memberi gambaran tentang tingkat dan batas maksimal dalam pemanfaatanya disuatu wilayah (Tangke, 2010). Menurut Guillen et al. (2016), perbaikan dalam status banyak stok ikan yang dimanfaatkan oleh armada perikanan, sekitar setengah masih tereksploitasi pada tingkat melebihi dari nilai $f_{\text {MSY. Mengurangi }}$ mortalitas penangkapan ikan agar stok ikan kembali menjadi lestari, umumnya bahwa dalam jangka menengah hingga jangka panjang, tangkapan dari stok tersebut lebih tinggi dari pada saat ini.

Tujuan dari penelitian ini yaitu mengetahui komoditas perikanan tangkap unggulan ikan pelagis kecil, mengetahui status pengusahaan sumberdaya ikan pelagis kecil dan menyusun skenario pengelolaan berkelanjutan sumberdaya komoditas unggulan ikan pelagis kecil di WPPNRI 712 dan 573 Provinsi Jawa Timur.

\section{METODE PENELITIAN}

\section{Metode Pengumpulan Data}

Metode yang digunakan dalam penelitian ini adalah metode deskriptif kuantitatif dan untuk analisi data dengan analisis Location Quotient (LQ), 
Walter Hilborn, serta pemograman STELLA (System Thinking, Experimental Learning Laboratory with Animation). Data Sekunder diperoleh berdasarkan dari buku statistik perikanan tangkap Provinsi Jawa Timur tahun 1990 - 2017,

\section{Metode Analisis Data}

\section{Penentuan Spesies Dominan}

Penetapan jenis ikan dominan digunakan untuk menentukan urutan spesies ikan demersal mulai dari yang tertinggi hingga terendah. Penentuan jenis ikan demersal dominan ini dilakukan menggunakan program Microsoft Excel dengan melihat urutan 5 jenis ikan dengan nilai produksi tertinggi (tabel data statistik nilai produksi perikanan laut menurut jenis ikan dan kabupaten/ kota) mulai tahun 1990 - 2017.

\section{Komoditas Unggulan}

Komoditas unggulan didapatkan menggunakan analisis Location Quotient (LQ) yang merupakan suatu indeks untuk membandingkan pangsa subwilayah dalam aktivitas perikanan tangkap dengan total pangsa aktivitas tersebut dalam total aktivitas wilayah. Menurut (Kohar dan Danta 2012, Hendayana 2003) nilai LQ diperoleh dengan menggunakan rumus sebagai berikut:

$$
\mathrm{LQ}=(\mathrm{Vi} / \mathrm{Vt}) /(\mathrm{Xi} / \mathrm{Xt})
$$

Dimana:

$\mathrm{Vi}=$ produksi total ikan jenis ikan i pada tingkat kabupaten

$\mathrm{Vt}=$ produksi total perikanan tangkap pada tingkat kabupaten

$\mathrm{Xi}=$ produksi total jenis ikan $\mathrm{i}$ pada tingkat provinsi

$\mathrm{Xt}=$ produksi total perikanan tangkap pada tingkat provinsi

Jika LQ > 1, maka ikan jenis i merupakan komoditas unggulan di tingkat kabupaten. Jika LQ $<1$, maka ikan jenis i bukan merupakan komoditas unggulan di tingkat kabupaten tersebut.

Kekenusa (2014), mengatakan bahwa Model Walter - Hilborn ini, menggunakan persamaan diferensial sederhana, dengan persamaan sebagai berikut:

$$
B_{(t+1)}=B_{t}+\left[r * B_{t}-\left(\frac{r}{k}\right) * B_{t}^{2}\right]-q * f_{t} * B_{t}
$$

Dimana

$\mathrm{B}(\mathrm{t}+1)=$ biomas populasi pada saat $(\mathrm{t}+1)$

$\mathrm{B}(\mathrm{t})=$ biomas populasi awal, pada saat $\mathrm{t}$

$r$ = laju pertumbuhan intrinsik stok biomas (konstan),

$\mathrm{k}$ = daya dukung maks lingkungan alami, 
Journal of Aquaculture Science

DOI: https://doi.org/10.31093/joas.v6i1IS.159

$\mathrm{q}=$ koefisien cathability $(0<\mathrm{q}<1)$

\section{Tingkat dan Status Pemanfaatan}

\section{Pengusahaan Sumberdaya Perikanan}

Menurut Latukonsina (2010),

pendugaan tingkat pemanfaatan

dilakukan untuk mengetahui seberapa besar tingkat pemanfaatan sumberdayaikan pelagis di Wilayah Pengelolaan Perikanan 712 Provinsi Jawa Timur. Pendugaan dilakukan dengan mempresentasekan jumlah hasil tangkapan pada tahun tertentu dengan nilai potensi maksimum lestari (YMSY) dengan persamaan berikut:

$$
\text { 『TP】_(Y)=Y_t/Y_JTB } \times 100 \%
$$

Dimana:

『TP】_( Y ): Tingkat Pemanfaatan

Yt : Rata - rata hasil tangkapan (ton)

YJTB : Potensi tangkapan lestari (ton)

Persamaan dari tingkat pengupayaan adalah sebagai berikut:

$$
\text { 『TP】_(f)=f_t/f_JTB } \times 100 \%
$$

Dimana:

『TP】_(f) : Tingkat pemanfaatan

$\mathrm{ft}$ : Rata - rata upaya penangkapan (trip)

f_JTB : Upaya penangkapan optimum (trip)
Menurut FAO (1995), menyatakan bahwa berdasarkan status pemanfaatan dan pengusahaan sumberdaya ikan dikelompokkan menjadi 6 yaitu:

- Unexploited: stok sumberdaya ikan yang belum tereksploitasi sehingga aktifitas penangkapan sangat dianjurkan untuk memperoleh manfaat dari produksi sumberdaya ikan.

- Lightly exploited: sumberdaya ikan baru tereksploitasi dalam jumlah kecil (25\%-50\%) dari nilai MSY. Peningkatan jumlah penangkapan sangat dianjurkan karena tidak menggangu kelestarian sumberdaya dan hasil tangkapan per unit upaya penangkapan (CpUE) masih meningkat.

- Moderately exploited: sumberdaya ikan baru tereksploitasi setengah (50-75\%) dari nilai MSY. Peningkatan jumlah upaya penangkapan masih dianjurkan tanpa menggangu kelestarian sumberdaya, nilai CpUE mungkin menurun.

- Fully-exploited: stok sumberdaya sudah tereksploitasi 
mendekati hingga setara dengan nilai $\quad(75 \%-100 \%)$ dari nilai MSY. Peningkatan upaya penangkapan sangat tidak dianjurkan walaupun jumlah tangkapan masih dapat meningkat karena dapat mengganggukelestarian sumberdaya ikan.

- Over exploited: stok sumberdaya telah menurun karena sumberdata telah dieksploitasi melebihi nilai (100\%-150\%) dari nilai MSY. Upaya penangkapan harus diturunkan karena sumberdaya ikan sudah terganggu.

- Depleted: stok sumberdaya ikan telah menurun dari tahun ketahun dan semakin drastis. Sumberdaya ikan telah tereksploitasi sebesar $(150 \%$ < dari nilai MSY).upaya penangkapan dikurangi dalam jumlah besar untuk menjaga kelestarian sumberdaya ikan.

\section{Skenario Pendugaan Stok Ikan Pelagis}

Parameter - parameter yang digunakan dalam skenario pendugaan stok diantaranya: laju pertumbuhan intrinsik (r), koefisien penangkapan (q), daya dukung lingkungan alami (k), dan potensi cadangan lestari (Be). Penentuan nilai cadangan stok ikan 10 tahun mendatang dapat menggunakan persamaan Walter - Hilbron, untuk digunakan nilai $r, q, k$ dan Be sebagai dasar untuk menghitung nilai stok cadangan ikan dari tahun ke tahun. Selanjutnya parameter - parameter tersebut diaplikasikan ke dalam software STELLA (System Thinking, Experimental Learning Laboratory with Animation) untuk dilakukannya skenario pendugaan stok pada ikan komoditas unggulan. Menurut Suwarto et al. (2015), program Stella 9.2. adalah suatu sistem berfikir yang diartikan sebagai sebuah paradigm, bahasa, metode dan seperangkat teknologi untuk membangun dan berbagi pemahaman tentang hal-hal dan proses yang memiliki hubungan saling ketergantungan.

\section{HASIL DAN PEMBAHASAN}

Sumberdaya perikanan pelagis di WPPNRI 712 Provinsi Jawa Timur pada tahun 1990-2017 sebesar 3.299.926,43 ton dengan total sumberdaya ikan pelagis kecil sebesar 2.530.209,21. Produksi tertinggi dari ikan pelagis kecil tahun 1990-2017 yaitu ikan layang dengan jumlah 
$757.740,9$ ton, dan produksi terendah yaitu ikan sunglir dengan jumlah 640,8 ton. Hal tersebut dikarenakan banyaknya permintaan ikan layang dan ikan kembung dari masyarakat. Permintaan tersebut menyebabkan banyak nelayan yang menangkap komoditas ikan layang dan kembung karena memiliki nilai ekonomis yang sangat tinggi. Produksi tertinggi ikan layang terdapat di Kabupaten Sumenep sedangkan untuk produksi tertinggi ikan kembung terdapat di Kabupaten Lamongan

Total produksi sumberdaya ikan pelagis di WPP 573 pada tahun 19902017 yaitu sebesar 1.538.036,262 ton. Produksi ikan pelagis tertinggi pada tahun 1990-2017 pada WPPNRI 573 adalah ikan lemuru dengan jumlah 513.613 ton dan produksi terendah adalah terubuk dengan jumlah 131,4 ton. Hal tersebut dapat terjadi karena banyaknya masyarakat yang menagkap jenis ikan tersebut dan mengkonsumsi ikan lemuru maupun tongkol. Produksi lemuru tertinggi terdapat pada Kabupaten Banyuwangi, sedangkan produksi tongkol tertinggi terdapat pada Kabupaten Trenggalek

\section{Komoditas Unggulan Perikanan Pelagis Kecil di WPPNRI 712 dan 573 Provinsi Jawa Timur}

Komoditas unggulan ikan pelagis kecil di Wilayah Pengelolaan Perikanan Negara Republik Indonesia (WPPNRI) 712 yaitu ikan kembung yang menjadi unggulan di 11 Kabupaten/Kota dengan total LQ sebesar 18,62. Komoditas unggulan kedua yaitu ikan tembang yang menjadi unggulan di 8 Kabupaten/Kota dengan total LQ sebesar 16,43. Komoditas unggulan ketiga yaitu ikan selar yang menjadi unggulan di 8 Kabupaten/Kota dengan total LQ sebesar 15,73 Komoditas unggulan ikan pelagis besar yaitu ikan tenggiri papan yang menjadi unggulan di 8 Kabupaten/Kota dengan total LQ sebesar 91,87. Komoditas unggulan kedua yaitu ikan cucut yang menjadi unggulan di 7 Kabupaten/Kota dengan total LQ sebesar 19,34. Komoditas unggulan ketiga yaitu ikan tenggiri yang menjadi unggulan di 7 Kabupaten/Kota dengan total LQ sebesar 18,92. Ikan kembung merupakan ikan dengan komoditas unggulan terbanyak di Kabupaten/Kota sehingga ikan kembung akan dapat terjadi berkurangnya sumberdaya sehingga untuk menjaga tetep 
berkelanjutan nantinya akan dilakukan analisis pendugaan lestari untuk mendapatkan status potensi dan kelestarian sumberdaya ikan agar tidak terjadi kelebihan upaya penangkapan yang dilakukan oleh nelayan. Hal tersebut dikarenakan adanya kemungkinan beberapa faktor lingkungan yang sangat cocok dari komoditas tersebut

Komoditas unggulan ikan pelagis kecil di Wilayah Pengelolaan Perikanan Negara Republik Indonesia (WPPNRI-573) Provinsi Jawa Timur memiliki nilai jumlah LQ terbanyak disetiap Kabupaten yaitu ikan lemuru dengan jumlah LQ 8 yang artinya komoditas lemuru menjadi unggulan pertama di Selatan Jawa Timur/ Sedangkan, komoditas unggulan ikan pelagis kecil kedua memiliki nilai jumlah LQ terbanyak kedua disetiap
Kabupaten yaitu ikan layang dengan dengan jumlah LQ 5 dan komoditas unggulan ikan pelagis kecil ketiga memiliki nilai jumlah LQ terbanyak ketiga disetiap Kabupaten yaitu ikan tetengkek dengan dengan jumlah LQ 3.komoditas unggulan ikan pelagis besar memiliki nilai jumlah LQ terbanyak disetiap Kabupaten yaitu ikan tuna dengan jumlah LQ 6 yang artinya komoditas tuna menjadi unggulan pertama, unggulan kedua yaitu ikan tenggiri papan dengan dengan jumlah LQ 5 dan komoditas unggulan ikan pelagis besar ketiga cakalang dengan dengan jumlah LQ 4.

Komoditas unggulan pelagis menurut Kabupaten di Wilayah Pengelolaan Perikanan Negara Republik Indonesia (WPPNRI-573) Provinsi Jawa Timur (tabel 1)

Tabel 1. Komoditas Unggulan Pelagis Menurut Kabupaten WPPNRI 573 Jawa Timur

\begin{tabular}{lllllll}
\hline \multirow{2}{*}{ No } & Kabupaten/Kota & Spesies Unggulan & & & \\
\cline { 3 - 6 } & 1 & 2 & 3 & 4 & 5 \\
\hline 1 & Banyuwangi & Lemuru & Sunglir & Daun Bambu & Terbang & Tenggiri Papan \\
2 & Jember & Lemuru & Cucut & Cakalang & Tuna & - \\
3 & Lumajang & Lemuru & Tetengkek & Tenggiri Papan & Layang & Cucut \\
4 & Malang & Sunglir & Tuna & Cakalang & Cakalang & Lemuru \\
5 & Blitar & Daun Bambu & Tuna & Lemuru & Layang & Tongkol \\
6 & Tulungagung & Julung-Julung & Lemuru & Tongkol & Teri & Layang \\
7 & Trenggalek & Lemuru & Layang & Tongkol & Tuna & Selar \\
8 & Pacitan & Tuna & Lemuru & Cakalang & Cucut & Layang \\
\hline
\end{tabular}


Komoditas unggulan Kabupaten/Kota

Jawa Timur. Hasil komoditas unggulan

ikan pelagis di wilayah Utara Jawa
Timur berdasarkan komoditas unggulan Kabupaten/Kota dapat dilihat pada (Tabel 2).

Tabel 2. Komoditas Unggulam Kabupaten/Kota Ikan Pelagis di WPPNRI 712

\begin{tabular}{|c|c|c|c|c|c|}
\hline \multirow{2}{*}{ Kabupaten/Kota } & \multicolumn{5}{|c|}{ Spesies Unggulan } \\
\hline & 1 & 2 & 3 & 4 & 5 \\
\hline Tuban & Tembang & Teri & Tetengkek & Japuh & Terbang \\
\hline Lamongan & Tetengkek & Sunglir & Daun Bambu & Layang & Terbang \\
\hline Gresik & Cucut & Tenggiri & Belanak & Teri & Tembang \\
\hline Kota Surabaya & Tenggiri Papan & Belanak & Teri & Tetengkek & - \\
\hline Bangkalan & Daun Bambu & Tenggiri & Selar & Cucut & Tembang \\
\hline Sampang & Lemuru & Kembung & Selar & Layang & - \\
\hline Pamekasan & Lemuru & Teri & Japuh & Tenggiri papan & Layang \\
\hline Sumenep & Tenggiri Papan & Tenggiri & Layang & Daun Bambu & $\begin{array}{l}\text { Cucut } \\
\text { Julung- }\end{array}$ \\
\hline Sidoarjo & Tetengkek & Teri & Cucut & Tenggiri papan & julung \\
\hline Pasuruan & Teri & Kembung & Tembang & Tenggiri & Cucut \\
\hline Kota Pasuruan & Tetengkek & Teri & Kembung & Tembang & Cucut \\
\hline $\begin{array}{l}\text { Probolinggo } \\
\text { Kota }\end{array}$ & Daun Bambu & Sunglir & Tenggiri papan & Lemuru & Tetengkek \\
\hline Probolinggo & Tenggiri Papan & Japuh & Lemuru & Daun Bambu & Terbang \\
\hline Situbondo & Lemuru & Layang & Sunglir & Tongkol & Kembung \\
\hline
\end{tabular}

Analisis Pendugaan Potensi Lestari

dan tingkat pemanfaatan Ikan

\section{kemuru di WPPRI 573}

Hasil analisis equilibrium state model Schaefer hasil tangkapan maksimum lestari ( $\mathrm{Y}_{\mathrm{MSY}}$ ) yaitu sebesar 30.112 ton/tahun dan upaya penangkapan maksimum lestari $\left(\mathrm{f}_{\mathrm{MSY}}\right)$ yaitu sebesar 84.263 trip/tahun. Selanjutnya untuk jumlah tangkapan yang diperbolehkan (JTB) didapatkan hasil $80 \%$ dari maximum sustainable yield (MSY), maka dapat diperoleh hasil tangkapan $\left(\mathrm{Y}_{\mathrm{JTB}}\right)$ yaitu sebesar penangkapan yang diperbolehkan $\left(\mathrm{f}_{\mathrm{JTB}}\right)$ yaitu sebesar 46.579 trip/tahun. Apabila upaya penangkapan dan hasil tangkapan terus ditingkatkan mencapai titik maximum sustainable yield (MSY), maka hasil tangkapan akan meningkat. Namun, apabila upaya penangkapan dan hasil tangkapan melebihi titik maximum sustainable yield (MSY), maka hasil tangkapan akan mengalami over fishing dan stok perikanan akan habis. Sedangkan tingkat pemanfaatan ikan lemuru ini memiliki nilai $120 \%$ yang artinya masuk dalam over fishing, itu 
berarti upaya penangkapan harus diturunkan, karena kelestarian sumberdaya terganggu. Pada tingkat pengusahaan memiliki nilai $240 \%$ yang artinya masuk kedalam depleted, itu berarti upaya penangkapan sangat dianjurkan untuk berhenti karena kelestarian sumberdaya sangat terancam

\section{Skenario Pengelolaan Perikanan WPPNRI 573 ikan lemuru}

Simulasi Penerapan Upaya

Penangkapan Sejumlah Effort Tahun 2017

Pada tahun 2017 jumlah upaya penangkapan tersebut sebesar 4.271 trip per tahun Model Walter-Hilborn dan didapatkan nilai $\mathrm{R}^{2} \quad$ (koefisien determinasi) sebesar 0,52 ; nilai laju pertumbuhan (r) sebesar -0,03; nilai daya dukung lingkungan (k) sebesar 9.170 ton/tahun; nilai koefisien upaya penangkapan (q) sebesar 9.1152. Untuk nilai cadangan biomassa (Be) sebesar 4.585 ton/tahun. hasil cadangan biomassa pada tahun 2018-2027 terus mengalamin kenaikan dengan cadangan biomassa pada tahun 2017 sebesar 0\%. Cadangan biomassa tersebut terus naik hingga $179 \%$ di tahun 2027. Mencari cadangan biomassa tersebut dengan menggunakan rumus Bfish/Be×100\%. Mengetahui kondisi tingkat pemanfaatan di WPPNRI 573 mengalami Over exploited, upaya penangkapan yang setara pada tahun 2017 dapat diterapkan karena akan menambah cadangan biomassa untuk 10 tahun mendatang (2018-2027). Tabel 1

Tabel 1. Hasil Pendugaan Cadangan Biomassa Menggunakan Effort Tahun 2017

\begin{tabular}{llllll}
\hline Years & Bfish & Pd-fish & Catch & Be & Cadangan Biomassa \\
\hline 2017 & 21,37 & 34,68 & 3,29 & $8.438,48$ & $0 \%$ \\
2027 & $15.094,30$ & $2.590,89$ & $2.320,84$ & $8.438,48$ & $179 \%$ \\
\hline
\end{tabular}

Simulasi Penerapan Upaya

Penangkapan Sejumlah Effort MSY

$\left(\mathbf{f}_{\text {MSY }}\right)$

Pendugaan biomassa cadangan lestari 10 tahun kedepan yaitu pada tahun 2018 sampai dengan 2027. Pada tahun 2017 jumlah upaya penangkapan lestari $\left(f_{M S Y}\right)$ tersebut sebesar 188.869 trip per menggunakan nilai laju pertumbuhan (r) sebesar - $-0,31$; nilai daya dukung lingkungan (k) sebesar 803.902 ton/tahun; nilai koefisien uapaya penangkapan (q) sebesar 0,0000181. Pada (Lampiran 6) menjelaskan bahwa untuk nilai cadangan biomassa (Be) sebesar 44011,4 ton. Cadangan 
biomassa (Be) didapat dari biomassa pada saat adanya penangkapan pada tahun 2018. Grafik hasil alokasi upaya penangkapan sejumlah effort MSY pelagis total tersaji pada hasil cadangan biomassa pada tahun 2018-2027 terus mengalamin penurunan dengan cadangan biomassa pada tahun 2017 sebesar $11 \%$. Cadangan biomassa tersebut terus menurun hingga $0 \%$ atau habis di tahun 2027. Mencari cadangan Tabel 3. . Hasil Pendugaan Cadangan Biomassa Menggunakan Effort Maksimum Lestari (fMSY)

\begin{tabular}{llllll}
\hline Years & Bfish & Pd-fish & Catch & Be & Cadangan Biomassa \\
\hline 2017 & 52,74 & 85,43 & 138,17 & $8.438,48$ & $1 \%$ \\
2027 & 0 & 0 & 0 & $8.438,48$ & $0 \%$ \\
\hline
\end{tabular}

Simulasi Penerapan Upaya cadangan biomassa tersebut dengan Penangkapan Sejumlah Effort JTB $\left(\mathbf{f}_{\mathrm{JTB}}\right)$

Pada tahun 2017 jumlah upaya penangkapan yang diperbolehkan $\left(\mathrm{f}_{\mathrm{JTB}}\right)$ tersebut sebesar 47.459 trip per tahun maka hasil cadangan biomassa pada tahun 2018-2027 terus mengalamin penurunan dengan cadangan biomassa pada tahun 2017 sebesar 1\%. Cadangan biomassa tersebut terus menurun hingga Tabel 4. Hasil Pendugaan Cadangan Biomassa Menggunakan Effort Yang Diperbolehkan (fJTB

\begin{tabular}{llllll}
\hline Years & Bfish & Pd-fish & Catch & Be & Cadangan Biomassa \\
\hline 2017 & 52,74 & 85,43 & 90,11 & $8.438,48$ & $1 \%$ \\
2027 & 21,22 & 34,45 & 36,26 & $8.438,48$ & $0 \%$ \\
\hline
\end{tabular}

biomassa tersebut dengan menggunakan rumus $\frac{B f i s h}{B e} \times 100 \%$. Mengetahui kondisi tingkat pemanfaatan di WPPNRI 573 mengalami Lighly exploited, upaya penangkapan lestari ( $f_{\text {MSY) }}$ yang setara pada tahun 2017 tidak dapat diterapkan karena akan mengurangi cadangan biomassa untuk 10 tahun mendatang (2018-2027 (tabel 3) menggunakan rumus $\frac{B f i s h}{B e} \times 100 \%$. Mengetahui kondisi tingkat mengalami Over exploited, upaya penangkapan yang diperbolehkan $\left(\mathrm{f}_{\mathrm{JTB}}\right)$ yang setara pada tahun 2017 tidak dapat diterapkan karena akan mengurangi cadangan biomassa untuk 10 tahun mendatang (2018-2027). (tabel 4) pemanfaatan di WPPNRI 573 
$\begin{array}{lrrr}\text { Skenario } & \text { Pengelolaan } & \text { Perikanan } \\ \text { WPPNRI } & 712 & \text { ikan } & \text { kembung }\end{array}$

\section{Rastrelliger $s p$}

Simulasi Penerapan Upaya

Penangkapan Sejumlah Effort Tahun

2017

Pendugaan nilai cadangan stok komoditas unggulan ikan kembung di Perairan Utara Jawa Timur menggunakan model Walter-Hilborn . didapatkan hasil biomassa pada tahun 2017-2027 mengalami penurunan sebesar 25.139,00 ton. Hasil pertumbuhan ikan kembung mengalami penurunan sebesar 16.521,02 ton. Hasil tangkapan ikan kembung mengalami penurunan sebesar $41.660,02$ ton dan cadangan biomassa pada tahun 2027 mengalami penurunan sebanyak $87 \%$ dari tahun 2017.(gambar 1)

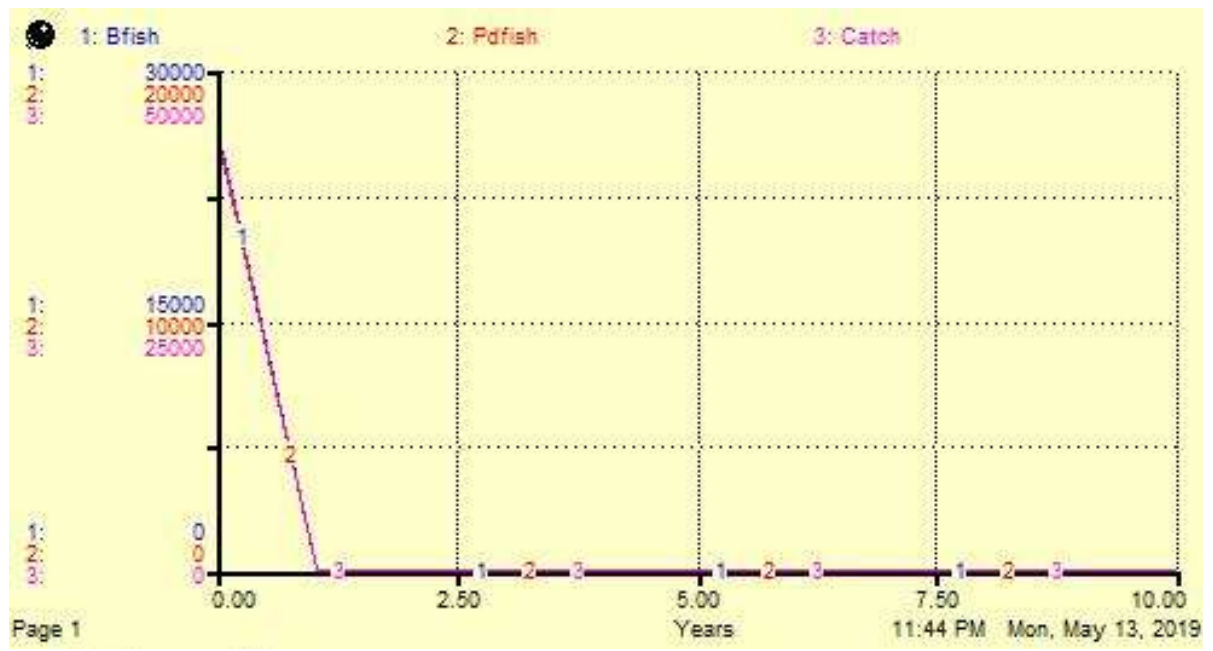

Gambar 1. Hasil Alokasi Upaya Penangkapan Ikan Kembung Setara dengan Effort Tahun 2017

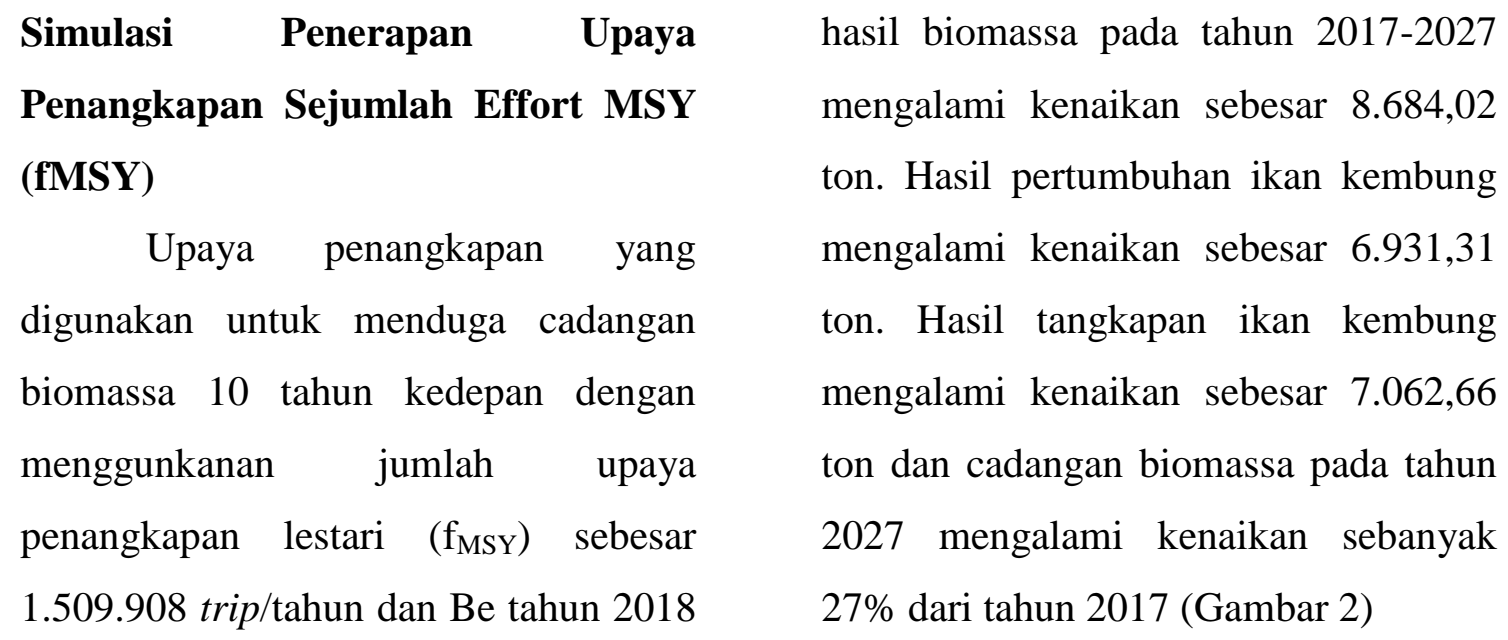
sebesar 3.488,7 ton/tahun. didapatkan 


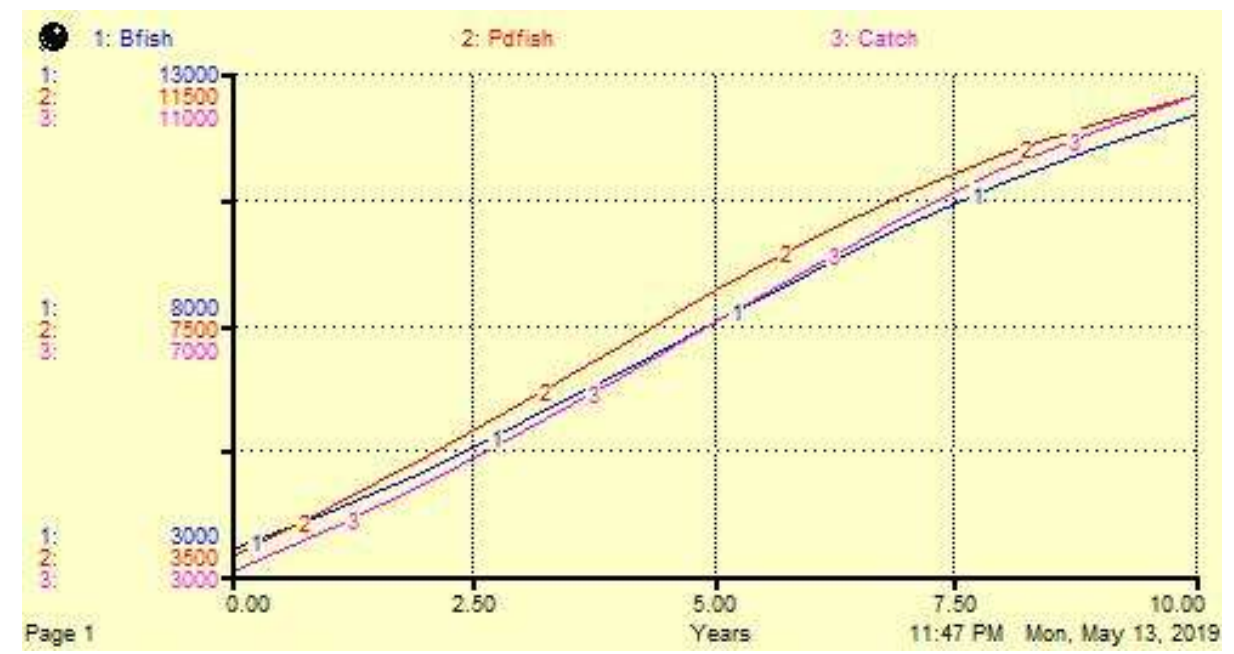

Gambar 2. Hasil Alokasi Upaya Penangkapan Ikan Kembung Sejumlah Effort MSY ( $\left.\mathrm{f}_{\mathrm{MSY}}\right)$

\section{Simulasi Penerapan Upaya}

Penangkapan Sejumlah Effort JTB

(f $\left.\mathbf{f}_{\text {JTB }}\right)$

Upaya penangkapan yang digunakan untuk menduga cadangan biomassa 10 tahun kedepan dengan menggunkanan jumlah upaya penangkapan diperbolehkan ( $f_{\text {Jтв}}$ ) sebesar 712.182 per tahun dan Be tahun 2018 sebesar $3.488,7$ ton/tahun. didapatkan hasil biomassa pada tahun 2017-2027 mengalami kenaikan sebesar 33.812,77 ton. Hasil pertumbuhan ikan kembung mengalami kenaikan sebesar 11.642,43 ton. Hasil tangkapan kembung mengalami kenaikan sebesar 13.938,50 ton dan cadangan biomassa pada tahun 2027 mengalami kenaikan sebanyak 117\% dari tahun 2017 (Gambar 3). Pendugaan cadangan biomassa dengan upaya penangkapan diperbolehkan $\left(\mathrm{f}_{\mathrm{JTB}}\right)$ mendapatkan hasil yang lebih besar dari pada upaya penangkapan setara dengan tahun 2017 dan upaya penangkapan lestari ( $f_{\mathrm{MSY}}$ ). Melihat kondisi perikanan kembung di Perairan Laut Jawa (WPPNRI 712) Provinsi Jawa Timur yang sudah dalam kondisi Over exploited, upaya penangkapan dapat diterapkan untuk pengelolaan perikanan untuk 10 tahun mendatang (2018-2027). Pengelolaan yang paling baik diantara 3 Effort sebaikanya menggunakan pengelolaan yang setara dengan upaya penangkapan diperbolehkan. Berdasarkan Peraturan Menteri Kelautan dan Perikanan Republik Indonesia, Nomor KEP 50/MEN/2017 tentang estimasi potensi, jumlah tangkapan yang diperbolehkan dan tingkat pemanfaatan sumberdaya ikan di WPPNRI 712 jenis ikan pelagis kecil memiliki jumlah tangkapan diperbolehkan yaitu 291.730 ton. 


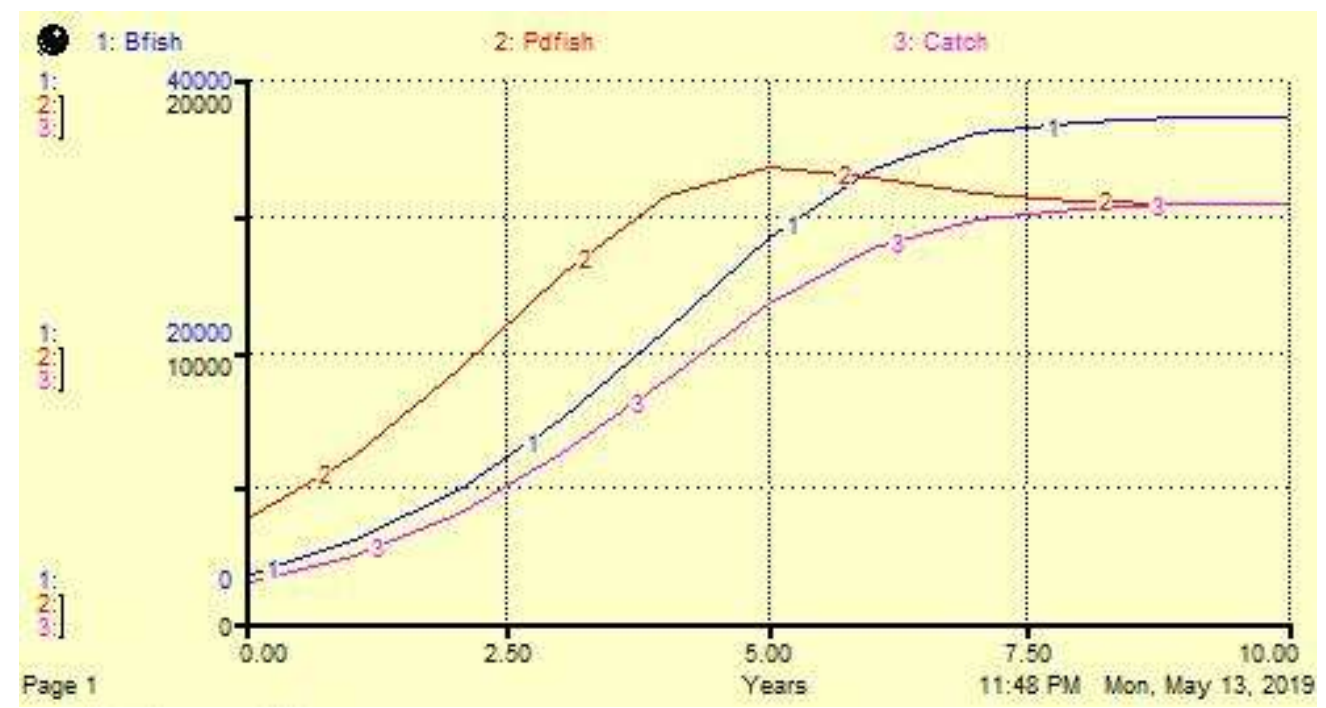

Gambar 1. Hasil Alokasi Upaya Penangkapan Ikan Kembung Sejumlah Effort JTB ( $\left.f_{\mathrm{JTB}}\right)$

\section{Kesimpulan}

- Perikanan Pelagislecil Di Wilayah Pengelolaan Perikanan Negara Republik Indonesia (WPPNRI) 712 Provinsi Jawa Timur

- Analisis Location Quotion (LQ) didapatkan ikan kembung, unggulan Kabupaten/Kota didapatkan ikan tetengkek,

- Tingkat pengusahaan ikan kembung sebagai komoditas unggulan Provinsi pelagis kecil yaitu $127 \%$ dengan status Over Exploited.

- Skenario pengelolaan berkelanjutan perikanan pelagis total untuk 10 tahun mendatang yaitu pada tahun 2018-2027 komoditas unggulan ikan kembung didapatkan cadangan biomasa tahun 2027 tertinggi yaitu pada alokasi upaya penangkapan diperbolehkan $\left(f_{\text {JTB }}\right)$ sebesar $129 \%$

- Perikanan Pelagislecil Di Wilayah Pengelolaan Perikanan Negara Republik Indonesia (WPPNRI) 573 Provinsi Jawa Timur

- Spesies yang termasuk dalam unggulan ikan pelagis menurut Provinsi yaitu: ikan lemuru untuk pelagis kecil, sedangkan unggulan ikan pelagis menurut Kabupaten adalah ikan sunglir

- Status perikanan pada, tingkat pengusahaan ikan lemuru sebesar $240 \%$ dengan status Depleted, tingkat pengusahaan ikan tuna sebesar $173 \%$ dengan status Depleted. Terakhir tingkat 
Journal of Aquaculture Science

DOI: https://doi.org/10.31093/joas.v6i1IS.159 pengusahaan untuk ikan sunglir sebesar $689 \%$ yang artinya masuk kedalam depleted

\section{DAFTAR PUSTAKA}

Branch Trevor A. 2008. Not all fisheries will be collapsed in 2048. Marine Policy 32: 38 - 39

Cushing, D. H., Shipley, O. N., \& Siskey, M. R. (2018). Pelagic Fishes. In Encyclopedia of Ocean Sciences (3rd ed.

FAO. (1995). CODE OF CONDUCT FOR. Code Of Product For Responsible Fisheries. Food and Agriculture Organization of The United Nations Rome.

FAO 2018 The State of World Fisheries and Aquaculture 2018-Meeting the Sustainable Development Goals Food and Agriculture Organization, Rome

Ghosh, B. dan T. K. Kar. 2013. Possible Ecosystem Impacts of Applying Maximum Sustainable Yield Policy in Food Chain Models. Journal of Theoretical Biology. 329: $6-14$

Gammanpila, M., Wijeyaratne, M. J. S., \& Amarasinghe, U. S. (2019). The dwindling community - based management strategies in the brush park fishery of a tropical estuary: Need for comanagement. Journal Ocean and Coastal Management, 167(September 2018): 145-157.

Guillen, J., Calvo, A., Carvalho, N., Casey, J., Lleonart, J., Maynou, F., dan Paulrud, A. 2016. Sustainability now or later? Estimating the bene fi ts of pathways to maximum sustainable yield for EU Northeast Atlantic fi sheries \$. Marine Policy 72, 72: 40-47. https://doi.org/10.1016/j.marpol.2 016.06.015

Hendayana, R. 2003. Aplikasi Metode Location Quotient (LQ) dalam Penentuan Komoditas Ungglan. Informatika Pertanian, 12: 1-21.

I. Palomera, M.P. Olivar, J. Salat, A. Sabatés, M. Coll, A. García, B. MoralesNin 2007 Small pelagic fish in the NW Mediterranean Sea: an ecological review. Prog. Oceanogr., 74 (2007), pp: 377396

J. Alheit, M.A. Peck Drivers of dynamics of small pelagic fish resources: biology, management and human factors Mar. Ecol. Prog. Ser.: 617-618 (2019), pp. 1-6, $10.3354 /$ meps 12985

Kekenusa, J. S., Rondonuwu, S. B., Paendong, M. S., dan Weku, W. C. D. 2014. Penentuan Status Pemanfaatan Dan Skenario Pengelolaan Ikan Tongkol ( Auxis rochei) yang Tertangkap di Perairan Kabupaten Siau-Tagulandang-Biaro Sulawesi Utara. Jurnal Ilmiah Sains, 14(2): 136-145.

Laapo, A. 2004. Model Ekonomi Perikanan Tangkap yang Berkelanjutan di Perairan Kabupaten Morowali. Institut Pertanian Bogor: Bogor.

Latukonsina, H. 2010. Pendugaan Potensi Dan Tingkat Pemanfaatan Ikan Layang ( Decapterus spp ) di Perairan Laut Flores Sulawesi Selatan. Jurnal Ilmiah agribisnis dan Perikanan (agrikan UMMUTernate): 3(2): 47-54.

Nelwan, A. F. P., Zainuddin, M., dan Kurnia M. 2015. Produktivitas Penangkapan Ikan Pelagis Besar Menggunakan Pancing Ulur yang Berpangkalan di Kabupaten Majene. Jurnal Perikanan ( $J$. Fish. Sci.), 6(2): 129-142.

Keputusan Menteri Kelautan dan Perikanan Republik Indonesia No. 50. 2017. Estimasi Potensi, Jumlah Tangkapan yang diperbolehkan, dan Tingkat Pemanfaatan Sumber Daya Ikan di Wilayah Pengelolaan Perikanan Negara Republik Indonesia Dengan.

Kohar, A. M. dan P. Danta. 2012. Analisis Komoditas Unggulan Perikanan Tangkap di Kabupaten Rembang. Jurnal Harpodon Borneo. 5 (2): $161-171$

Rasyid, A. 2009. Distribusi Klorofil-A Pada Musim Timur Di Perairan Spermonde Propinsi Sulawesi Selatan Distribution Of 
Chlorophyll-A In The Season Of East In Spermonde Aquatic South Sulawesi. J. Sains \& Teknologi: 9(2), 105-116.

Suwarto., Agustinus, T. A., dan Irzal, E. 2015. Perancangan Model Pertanian Terpadu Tanaman-Ternak dan Tanaman-Ikan di Perkampungan Teknologi Telo , Riau and CropFish at Telo Technology Village, Riau. J. Agron. Indonesia, 43(2): 168-177.

Tangke, U. 2010. Analisis Potensi Dan Tingkat Pemanfaatan Sumberdaya Ikan Kuwe ( Carangidae $s p$ ) di Perairan Laut Flores Provinsi Sulawesi Selatan. Jurnal Ilmiah agribisnis dan Perikanan (agrikan UMMU-Ternate). 3(2): 31-38.

Worm Boris, Edward B. Barbier,Nicola Beaumont,J. Emmett Duffy, Carl Folke, Benjamin S. Halpern, Jeremy B. C. Jackson, Heike K. Lotze, Fiorenza Micheli, Stephen R. Palumbi, Enric Sala, Kimberley A. Selkoe, John J. Stachowicz, Reg Watson 2006. Impacts of Biodiversity Loss on Ocean Ecosystem Services.S cience 3:Vol. 314. no. 5800, pp: $787-790$ 